\title{
Is FTO gene variant related to cancer risk independently of adiposity? An updated meta-analysis of 129,467 cases and 290,633 controls
}

\author{
Yu Kang ${ }^{2}$, Fang Liu ${ }^{1}$ and Yao Liu ${ }^{1}$ \\ ${ }^{1}$ Department of Pharmacy, Southwest Hospital, Third Military Medical University, Chongqing, 400038, China \\ ${ }^{2}$ Department of Oncology, Southwest Hospital, Third Military Medical University, Chongqing, 400038, China \\ Correspondence to: Yao Liv, email: swhliuyao@163.com \\ Keywords: FTO, meta-analysis, cancer, obesity \\ Received: December 28, $2016 \quad$ Accepted: February 28, $2017 \quad$ Published: March 22, 2017 \\ Copyright: Kang et al. This is an open-access article distributed under the terms of the Creative Commons Attribution License 3.0 \\ (CC BY 3.0), which permits unrestricted use, distribution, and reproduction in any medium, provided the original author and source \\ are credited.
}

\section{ABSTRACT}

Previous studies have examined the association between the fat mass and obesityassociated (FTO) gene variant and risk of cancer in diverse populations. However, the results have been inconsistent. PubMed and Embase databases were searched for the eligible publications in English language by July, 2016. The associations of FTO variants with cancer risk were estimated by calculating the pooled odds ratios and $95 \%$ confidence intervals by meta-analyses. A total of 27 publications (129,467 cancer cases and 290,633 normal controls) were included in our meta-analysis. Overall, FTO rs9939609 variant (or its proxy) was not associated with cancer risk without adjustment for body mass index, as well as additional adjustment for body mss index. However, FTO rs9939609 variant was associated with some types of cancer in the subgroup analysis. In addition, overall, there was no significant association between FTO rs1477196 variant and cancer risk regardless of adjustment for body mass index. However, FTO rs11075995 variant risk allele was associated with breast cancer risk without adjustment for body mass index, but the association disappeared with further adjustment for body mass index. This study overall does not support that the FTO variant is associated with cancer risk independently of the adiposity.

\section{INTRODUCTION}

In 2007, the fat mass and obesity associated (FTO) gene was reported as the first obesity related gene by the genomewide association studies (GWAS) in Caucasian population [1, 2]. Subsequently, the following studies confirmed the positive associations between single nucleotide polymorphisms (SNPs) in/near FTO gene and obesity risk in diverse populations [3-5].

FTO gene was found to affect the function of the central nervous system, as well as adipose tissue at a peripheral level. As obesity is a well established risk factor for most types of cancer, it is interesting and important to investigate whether FTO SNPs are associated with risk of cancer. Up to now, a total of 27 publications have examined the associations between FTO SNPs and risk of cancer [6-32]. However, the results have been inconsistent. Three meta-analyses have summarized the associations between
FTO SNPs and risk of cancer [33-35]; however, there are several limitations for them. First, they did not address whether the associations were mediated through body mass index (BMI)/obesity. Second, many eligible studies were omitted. Third, two of three from the same study team examined the association between each of two SNPs (rs8050136[34] and rs9939609[35]) in/near FTO gene and cancer risk. It is illogical to do the separate analyses for these two SNPs as they are in strong linkage disequilibrium (LD, $\left.r^{2}>0.90\right)$ in both European and Asian populations.

Therefore, we aimed to perform an updated metaanalysis to investigate the associations between FTO rs9939609 SNP (or any proxy SNP, $r^{2}>0.90$ ) and other SNPs which are not in tight LD with rs9939609 SNP (such as rs1477196 and rs11075995) and cancer risk. In addition, we also aimed to examine whether the associations are independent of adiposity. 


\section{RESULTS}

\section{Characteristics of the studies}

A flow chart describing the process of inclusion/ exclusion of studies is presented in Figure 1. The literature search identified a total of 238 potentially relevant articles. At last, a total of 27 publications $(129,467$ cancer cases and 290,633 normal controls) were included in our metaanalysis. There were 24 publications (113780 cases and 210593 controls) for FTO rs9939609 SNP, 5 publications (1594 cases and 2034 controls) for FTO rs1477196 SNP, and 3 publications (14144 cases and 79973 controls) for rs11075995 variant. All three SNPs in the each of included studies were in Hardy-Weinberg Equivalent. The characteristics of the included studies are listed in Table 1.

\section{Meta-analysis results}

Overall, FTO rs9939609 SNP was not associated with cancer risk without adjustment for BMI ( $\mathrm{OR}=1.01$, $95 \% \mathrm{CI}=0.97-1.05)$. In the subgroup analysis by race/ ethnicity, before adjustment for BMI, there was no any significant associations in European population, East Asian population, Middle East population and mixed population (all $P>0.05$ ) (Figure 2). After adjustment for BMI, FTO rs9939609 SNP risk allele was associated with cancer risk in East Asian population $(\mathrm{OR}=1.29,95 \% \mathrm{CI}=1.06-1.57)$ and African population $(\mathrm{OR}=1.21,95 \% \mathrm{CI}=1.06-1.38)$, but not in European population, Middle East population and Mixed population (all $P>0.05$ ) (Figure 3).In the subgroup analysis by cancer type, FTO rs9939609 SNP risk allele marginally increased risk of endometrial cancer $(\mathrm{OR}=1.07$, $95 \% \mathrm{CI}=1.00-1.14)$ and pancreatic cancer $(\mathrm{OR}=1.12$, $95 \% \mathrm{CI}=1.04-1.21)$, while it marginally decreased risk of breast cancer $(\mathrm{OR}=0.94,95 \% \mathrm{CI}=0.92-0.96)$ (Table 2 and Supplementary Figure 1). Overall, there was also no significant association between FTO rs9939609 SNP and cancer risk with adjustment for BMI $(\mathrm{OR}=1.01$, 95\%CI $=0.93-1.10) . \quad F T O$ rs9939609 SNP risk allele marginally decreased risk of prostate cancer $(\mathrm{OR}=0.93$, $95 \% \mathrm{CI}=0.88-0.99$ ), while it marginally increased risk of breast cancer $(\mathrm{OR}=1.12,95 \% \mathrm{CI}=0.99-1.26)$ (Table 2 and Supplementary Figure 2).

There was no significant association between FTO rs1477196 SNP and cancer risk without $(\mathrm{OR}=1.07$, $95 \% \mathrm{CI}=0.97-1.20)$ or with $(\mathrm{OR}=1.08,95 \% \mathrm{CI}=0.97-1.21)$ adjustment for BMI. However, we found a significant association between FTO rs1477196 SNP and risk of thyroid cancer without $(\mathrm{OR}=1.31,95 \% \mathrm{CI}=1.07-1.61)$ or with $(\mathrm{OR}=1.32,95 \% \mathrm{CI}=1.08-1.62)$ adjustment for $\mathrm{BMI}$ (Table 2 and Supplementary Figures 3-4).

FTO rs11075995 SNP risk allele was associated with breast cancer risk without adjustment for $\mathrm{BMI}(\mathrm{OR}=1.08$,

\section{Records identified via Pubmed and Embase databases $(\mathrm{n}=238$ )}

Excision after screen title or abstract $(n=185)$

\section{Records remained $(\mathrm{n}=53$ )}

Records excluded ( $\mathrm{n}=26$ )

2 reviews

3 meta-analyses

1 letter

20 not focus on association between

FTO SNP and cancer risk

\section{Full-text articles eligible for meta-analysis $(\mathrm{n}=27)$}

Figure 1: Flowchart for inclusion/exclusion of studies. 
Table 1: The detailed characteristics of the included studies in the meta-analysis

\begin{tabular}{|c|c|c|c|c|c|c|c|c|c|c|}
\hline Study * & Country & Ethnicity & $\begin{array}{l}\text { Type of } \\
\text { cancer }\end{array}$ & $\begin{array}{l}\text { No. of } \\
\text { cases }\end{array}$ & $\begin{array}{c}\text { No. of } \\
\text { controls }\end{array}$ & OR & \multicolumn{2}{|c|}{$95 \%$ CI } & SNP & $\begin{array}{c}\text { Adjustment } \\
\text { for BMI }\end{array}$ \\
\hline $\begin{array}{l}\text { Brennan, } \\
2009 \text { [6] }\end{array}$ & $\begin{array}{l}\text { Czech Republic, } \\
\text { Hungary, Poland, } \\
\text { Romania, Russia, } \\
\text { and Slovakia }\end{array}$ & European & Lung cancer & 2250 & 3052 & 0.92 & 0.84 & 1.00 & rs9939609 & No \\
\hline $\begin{array}{l}\text { Brennan, } \\
2009[6]\end{array}$ & $\begin{array}{l}\text { Czech Republic, } \\
\text { Hungary, Poland, } \\
\text { Romania, Russia, } \\
\text { and Slovakia }\end{array}$ & European & Kidney cancer & 954 & 3052 & 1.06 & 0.95 & 1.19 & rs9939609 & No \\
\hline $\begin{array}{l}\text { Brennan, } \\
2009 \text { [6] }\end{array}$ & $\begin{array}{l}\text { Czech Republic, } \\
\text { Hungary, Poland, } \\
\text { Romania, Russia, } \\
\text { and Slovakia }\end{array}$ & European & $\begin{array}{l}\text { Upper } \\
\text { aerodigestive } \\
\text { cancer }\end{array}$ & 811 & 3052 & 0.98 & 0.87 & 1.12 & rs9939609 & No \\
\hline $\begin{array}{l}\text { Gaudet, } 2010 \\
\text { [7] }\end{array}$ & $\begin{array}{l}\text { USA and } \\
\text { Australia }\end{array}$ & Mixed & $\begin{array}{l}\text { Endometrial } \\
\text { cancer }\end{array}$ & 417 & 406 & 1.05 & 0.86 & 1.28 & rs8050136 & No \\
\hline $\begin{array}{l}\text { Lewis, } 2010 \\
{[8]}\end{array}$ & UK & European & $\begin{array}{l}\text { Prostate } \\
\text { cancer }\end{array}$ & 1550 & 1815 & 0.94 & 0.85 & 1.03 & rs9939609 & Yes \\
\hline $\begin{array}{l}\text { Meyer, } 2010 \\
\text { [9] }\end{array}$ & USA & Mixed & $\begin{array}{l}\text { Prostate } \\
\text { cancer }\end{array}$ & 379 & 5874 & 1.04 & 0.91 & 1.20 & rs8050136 & No \\
\hline $\begin{array}{l}\text { Delahanty, } \\
2011 \text { [10] }\end{array}$ & China & East Asian & $\begin{array}{c}\text { Endometrial } \\
\text { cancer }\end{array}$ & 832 & 2049 & 1.07 & 0.89 & 1.29 & rs9939609 & No \\
\hline \multirow[t]{4}{*}{$\begin{array}{l}\text { Kaklamani, } \\
2011 \text { [11] }\end{array}$} & USA & Mixed & Breast cancer & 302 & 349 & 0.992 & 0.78 & 1.26 & rs9939609 & No \\
\hline & & & & & & 0.975 & 0.77 & 1.23 & & Yes \\
\hline & & & & & & 1.408 & 1.11 & 1.79 & rs 1477196 & No \\
\hline & & & & & & 1.447 & 1.13 & 1.85 & & Yes \\
\hline \multirow[t]{2}{*}{$\begin{array}{l}\text { Lurie, } 2011 \\
{[12]}\end{array}$} & $\begin{array}{l}\text { Australia, USA, } \\
\text { Poland, and } \\
\text { Canada }\end{array}$ & European & $\begin{array}{c}\text { Endometrial } \\
\text { cancer }\end{array}$ & 3561 & 5167 & 1.07 & 0.99 & 1.14 & rs9939609 & No \\
\hline & & & & & & 1.01 & 0.94 & 1.08 & & Yes \\
\hline $\begin{array}{l}\text { Pierce, } 2011 \\
{[13]}\end{array}$ & $\begin{array}{l}\text { Finland, USA, } \\
\text { China, France, } \\
\text { Germany, } \\
\text { Greece, Italy, } \\
\text { The Netherlands, } \\
\text { Spain, and the } \\
\text { UK }\end{array}$ & European & $\begin{array}{l}\text { Pancreatic } \\
\text { cancer }\end{array}$ & 1763 & 1802 & 1.12 & 1.02 & 1.23 & rs 8050136 & No \\
\hline \multirow[t]{2}{*}{$\begin{array}{l}\text { Tang, } 2011 \\
{[14]}\end{array}$} & USA & Mixed & $\begin{array}{l}\text { Pancreatic } \\
\text { cancer }\end{array}$ & 1053 & 1130 & 1.08 & 0.96 & 1.22 & rs9939609 & No \\
\hline & & & & & & 1.03 & 0.80 & 1.30 & & Yes \\
\hline $\begin{array}{l}\text { Brooks, } 2012 \\
{[15]}\end{array}$ & $\begin{array}{l}\text { USA and } \\
\text { Denmark }\end{array}$ & European & Breast cancer & 643 & 1271 & 1.1 & 0.9 & 1.3 & rs9939609 & No \\
\hline $\begin{array}{l}\text { Hubacek, } \\
2012 \text { [16] }\end{array}$ & $\begin{array}{l}\text { Czech Republic, } \\
\text { Hungary, Poland, } \\
\text { Romania, Russia, } \\
\text { and Slovakia }\end{array}$ & European & $\begin{array}{l}\text { Colorectal } \\
\text { cancer }\end{array}$ & 1005 & 6827 & 1.02 & 0.93 & 1.13 & rs17817449 & No \\
\hline \multirow[t]{3}{*}{$\begin{array}{l}\text { Kitahara, } \\
2012 \text { [17] }\end{array}$} & USA & European & $\begin{array}{l}\text { Thyroid } \\
\text { cancer }\end{array}$ & 341 & 444 & 0.77 & 0.62 & 0.94 & rs9939609 & No \\
\hline & & & & & & 0.76 & 0.61 & 0.93 & & Yes \\
\hline & & & & & & 1.31 & 1.07 & 1.61 & s1477196 & No \\
\hline
\end{tabular}




\begin{tabular}{|c|c|c|c|c|c|c|c|c|c|c|}
\hline \multirow[t]{2}{*}{ Study * } & \multirow[t]{2}{*}{ Country } & \multirow[t]{2}{*}{ Ethnicity } & \multirow{2}{*}{$\begin{array}{l}\text { Type of } \\
\text { cancer }\end{array}$} & \multirow{2}{*}{$\begin{array}{l}\text { No. of } \\
\text { cases }\end{array}$} & \multirow{2}{*}{$\begin{array}{c}\text { No. of } \\
\text { controls }\end{array}$} & \multirow{2}{*}{$\begin{array}{c}\text { OR } \\
1.32\end{array}$} & \multicolumn{2}{|c|}{$95 \%$ CI } & \multirow[t]{2}{*}{ SNP } & \multirow{2}{*}{$\begin{array}{c}\begin{array}{c}\text { Adjustment } \\
\text { for BMI }\end{array} \\
\text { Yes }\end{array}$} \\
\hline & & & & & & & 1.07 & 1.61 & & \\
\hline $\begin{array}{l}\text { Kusinska, } \\
2012 \text { [18] }\end{array}$ & Poland & European & Breast cancer & 134 & 357 & 1.05 & 0.68 & 1.61 & rs9939609 & No \\
\hline $\begin{array}{l}\text { Lim, } 2012 \\
{[19]}\end{array}$ & USA & Mixed & $\begin{array}{l}\text { Colorectal } \\
\text { cancer }\end{array}$ & 2033 & 9640 & 1.02 & 0.93 & 1.11 & rs9939609 & No \\
\hline $\begin{array}{l}\text { Machiela, } \\
2012 \text { [20] }\end{array}$ & $\begin{array}{l}\text { USA and several } \\
\text { European } \\
\text { countries }\end{array}$ & European & $\begin{array}{l}\text { Prostate } \\
\text { cancer }\end{array}$ & 2782 & 4458 & 0.93 & 0.86 & 1.00 & rs9939609 & Yes \\
\hline $\begin{array}{l}\text { Tarabra, } 2012 \\
{[21]}\end{array}$ & Italy & European & $\begin{array}{l}\text { Colorectal } \\
\text { cancer }\end{array}$ & 341 & 311 & 1.01 & 0.81 & 1.25 & rs9939609 & No \\
\hline \multirow[t]{2}{*}{$\begin{array}{l}\text { Akilzhanova, } \\
2013 \text { [22] }\end{array}$} & Kazakhstan & European & Breast cancer & 315 & 604 & 0.96 & 0.78 & 1.17 & rs1477196 & No \\
\hline & & & & & & 0.96 & 0.78 & 1.17 & & Yes \\
\hline \multirow[t]{2}{*}{$\begin{array}{l}\text { da Cunha, } \\
2013 \text { [23] }\end{array}$} & Brazil & European & Breast cancer & 100 & 148 & 0.86 & 0.60 & 1.25 & rs9939609 & No \\
\hline & & & & & & 0.87 & 0.61 & 1.26 & & Yes \\
\hline \multirow[t]{2}{*}{$\begin{array}{l}\text { Garcia- } \\
\text { Closas, } 2013 \\
{[24]}\end{array}$} & $\begin{array}{l}\text { USA and many } \\
\text { European } \\
\text { countries }\end{array}$ & European & Breast cancer & 10706 & 76647 & 1.11 & 1.07 & 1.15 & rs11075995 & No \\
\hline & & & & 3071 & 20130 & 1.16 & 1.09 & 1.24 & & Yes \\
\hline $\begin{array}{l}\text { Iles, } 2013 \\
{[25]}\end{array}$ & $\begin{array}{l}\text { European } \\
\text { countries }\end{array}$ & European & Melanoma & 13060 & 60726 & 1.03 & 0.97 & 1.10 & rs8050136 & No \\
\hline \multirow[t]{2}{*}{$\begin{array}{l}\text { Lin, } 2013 \\
{[26]}\end{array}$} & Japan & East Asian & $\begin{array}{l}\text { Pancreatic } \\
\text { cancer }\end{array}$ & 360 & 400 & 1.33 & 1.04 & 1.72 & rs9939609 & No \\
\hline & & & & & & 1.41 & 1.07 & 1.85 & & Yes \\
\hline $\begin{array}{l}\text { Long, } 2013 \\
{[27]}\end{array}$ & USA & African & Breast cancer & 1113 & 930 & 1.21 & 1.06 & 1.37 & rs17817449 & Yes \\
\hline $\begin{array}{l}\text { Zheng, } 2013 \\
{[28]}\end{array}$ & $\begin{array}{c}\text { China, Korea, } \\
\text { Japan and } \\
\text { Thailand }\end{array}$ & East Asian & Breast cancer & 16797 & 18983 & 0.92 & 0.88 & 0.97 & rs17817449 & No \\
\hline $\begin{array}{l}\text { Zhang, } 2014 \\
\text { [29] }\end{array}$ & China & East Asian & Breast cancer & 2901 & 2789 & 1.06 & 0.98 & 1.14 & rs11075995 & No \\
\hline \multirow[t]{4}{*}{$\begin{array}{l}\text { Mojaver, } \\
2015 \text { [30] }\end{array}$} & Iran & $\begin{array}{l}\text { Middle } \\
\text { East }\end{array}$ & Breast cancer & 99 & 100 & 0.85 & 0.51 & 1.41 & rs9939609 & No \\
\hline & & & & & & 1.215 & 0.683 & 2.161 & & Yes \\
\hline & & & & & & 1.14 & 0.64 & 2.01 & rs1477196 & No \\
\hline & & & & & & 0.890 & 0.464 & 1.707 & & Yes \\
\hline \multirow[t]{6}{*}{$\begin{array}{l}\text { Zeng,2015 } \\
{[31]}\end{array}$} & China & East Asian & Breast cancer & 537 & 537 & 1.19 & 0.90 & 1.57 & rs9939609 & No \\
\hline & & & & & & 1.18 & 0.89 & 1.56 & & Yes \\
\hline & & & & & & 0.73 & 0.58 & 0.93 & rs 1477196 & No \\
\hline & & & & & & 0.75 & 0.59 & 0.96 & & Yes \\
\hline & & & & & & 0.90 & 0.71 & 1.15 & rs11075995 & No \\
\hline & & & & & & 0.94 & 0.73 & 1.20 & & Yes \\
\hline $\begin{array}{l}\text { Zhao, } \\
2016[32]\end{array}$ & $\begin{array}{l}\text { Several European } \\
\text { countries }\end{array}$ & European & Breast cancer & 62328 & 83817 & 0.94 & 0.92 & 0.95 & rs9939609 & No \\
\hline
\end{tabular}

* All included studies were case-control designed. 
95\% $\mathrm{CI}=1.01-1.15$ ) (Table 2 and Supplementary Figure 5). However, the significant association disappeared after adjustment for $\mathrm{BMI}(\mathrm{OR}=1.08,95 \% \mathrm{CI}=0.89-1.31)$ (Table 2 and Supplementary Figure 6).

\section{Publication bias}

There was no publication bias for FTO rs9939609, rs1477196 or rs11075995 SNP using Begg's test or Egger's test (all $P>0.05$ ).

\section{DISCUSSION}

Our updated meta-analysis shows that FTO rs9939609 SNP was associated with some types of cancer, such as endometrial cancer, pancreatic cancer and breast cancer without adjustment for BMI, while it was still associated with breast cancer and prostate cancer with adjustment for BMI. In addition, FTO rs1477196 SNP was associated with thyroid cancer independently of BMI and FTO rs11075995 SNP was associated with breast cancer dependently on BMI.
Study

ID

European

Brennan, 2009

Brennan, 2009

Brennan, 2009

Lurie, 2011

Pieroe, 2011

Brooks, 2012

Hubacek, 2012

Kitahara, 2012

Kusinła, 2012

Tarabra, 2012

da Cunitia, 2013

lles, 2013

$Z h_{30}, 2016$

Subtotal (l-squared $=72.3 \%, p=0.000$ )

East Asian

Delahanty, 2011

Lin, 2013

Zheng. 2013

Zeng.2015

Subtotal (1-squared $=76.2 \%, p=0.006$ )

Middle East

Mojaver, 2015

Subtotal (l-squared $=. \%, p=$.

Mixed

Gaudet,2010

Mileyer, 2010

Kaklamani, 2011

Tang. 2011

Lim, 2012

Subtotal (l-squared $=0.0 \%, p=0.949$ )

Dwerall (l-squared $=65.8 \%, p=0.000$ )

NDTE: 'illeights are from random effect analysis

51

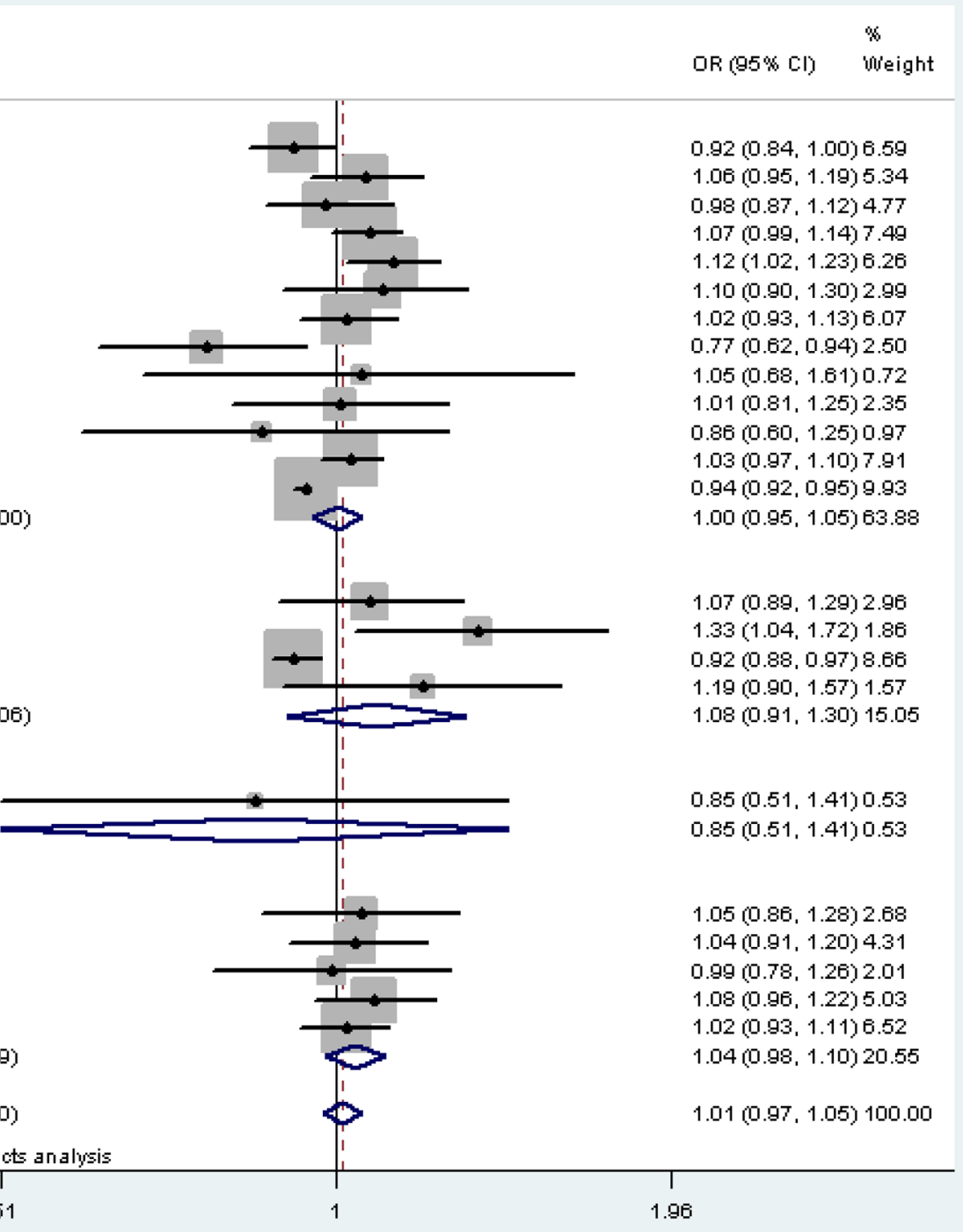

Figure 2: Forest plot of the effect of FTO rs9939609 on risk of cancer by race/ethnicity without adjustment for body mass index. 
Several meta-analyses have addressed the association between FTO SNP and risk of diabetes, [36] hypertension, [37] cardiovascular disease, [38] polycystic ovary syndrome [39] and mortality [40]. Most of these meta-analyses supported FTO SNP was associated with health outcomes independently of adiposity. A meta-analysis of data from 169,551 Caucasian adults showed that the hazards ratio (HR) for the A minor allele of the FTO rs9939609 SNP was 1.02 (1.00-1.04, $P=0.097)$, but the association disappeared after adjustment for $\mathrm{BMI}(\mathrm{HR}=1.00 ; 0.98-1.03, P=0.662)$ [40]. These results suggested that FTO SNP risk allele increases risk of mortality directly through adiposity pathway.

It seemed that FTO rs9939609 SNP played different roles in the development of different cancer, as well as in different populations. Previous studies demonstrated that BMI was associated with risk of common cancer, but its association with some cancer types differed between sexes and different ethnic populations [41]. As FTO SNP rs9939609 was strongly associated with BMI, it is not surprising that this variant was associated with some types of cancer but not with other types of cancer.

The FTO protein is highly expressed in hypothalamus, as well as in many other tissues: mesenteric fat, adipose, pancreatic, and liver. It regulates the global metabolic rate, energy expenditure, energy homeostasis, body size and body fat accumulation [42]. FTO rs8050136 was reported to preferentially bind to cut-like homeobox (CUTL1) in human fibroblast DNA and silencing this transcriptional factor CUTL1 could lead to decreased FTO expression in fibroblasts [43]. In addition, FTO SNP was strongly associated with expression of a tumor suppressor/cell cycle-

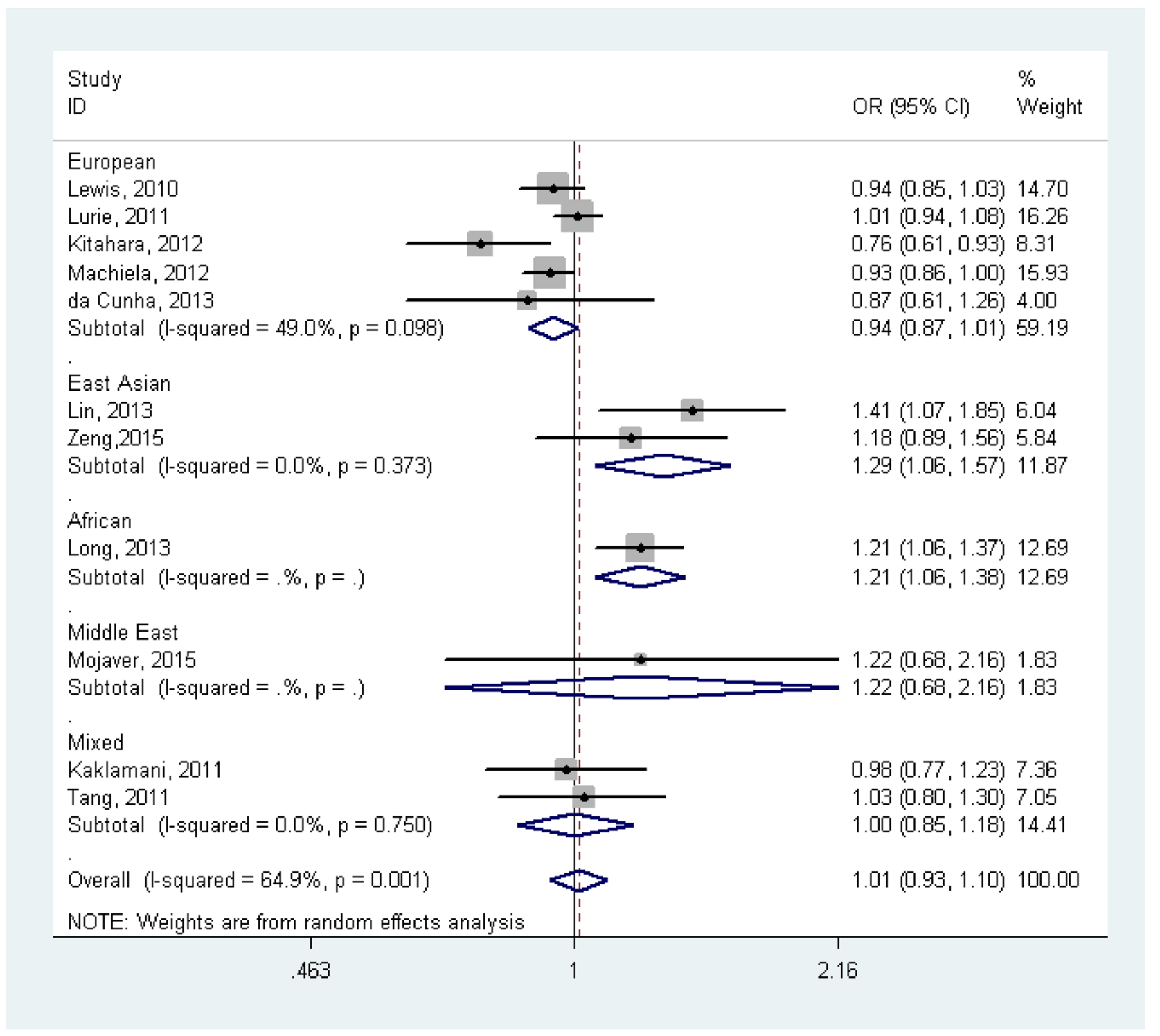

Figure 3: Forest plot of the effect of FTO rs9939609 on risk of cancer by race/ethnicity with adjustment for body mass index. 
Table 2: Associations between $F$ TO variants and cancer risk by cancer type

\begin{tabular}{|c|c|c|c|c|}
\hline & OR & $95 \% \mathrm{CI}$ & $I^{2}(\%)$ & $\boldsymbol{P}_{\text {for heterogeneitv }}$ \\
\hline \multicolumn{5}{|l|}{ rs9939609 } \\
\hline \multicolumn{5}{|l|}{$\begin{array}{l}\text { Before BMI } \\
\text { adjustment }\end{array}$} \\
\hline All & 1.01 & $0.97-1.05$ & 65.8 & $<0.001$ \\
\hline $\begin{array}{l}\text { Endometrial } \\
\text { cancer }\end{array}$ & 1.07 & $1.00-1.14$ & 0 & 0.985 \\
\hline Breast cancer & 0.94 & $0.92-0.96$ & 1.8 & 0.416 \\
\hline Pancreatic cancer & 1.12 & $1.04-1.21$ & 6.8 & 0.342 \\
\hline Colorectal cancer & 1.02 & 0.96-1.09 & 0 & 0.996 \\
\hline Others & 0.98 & $0.92-1.05$ & 57.4 & 0.038 \\
\hline \multicolumn{5}{|l|}{$\begin{array}{l}\text { After BMI } \\
\text { adjustment }\end{array}$} \\
\hline All & 1.01 & $0.93-1.10$ & 64.9 & 0.001 \\
\hline Breast cancer & 1.12 & $0.99-1.26$ & 14.2 & 0.324 \\
\hline Pancreatic cancer & 1.20 & $0.88-1.63$ & 64.7 & 0.093 \\
\hline Prostate cancer & 0.93 & $0.88-0.99$ & 0 & 0.864 \\
\hline Others & 0.89 & $0.68-1.18$ & 84.1 & 0.012 \\
\hline \multicolumn{5}{|l|}{ rs1477196 } \\
\hline \multicolumn{5}{|l|}{$\begin{array}{l}\text { Before BMI } \\
\text { adjustment }\end{array}$} \\
\hline All & 1.07 & $0.97-1.20$ & 80.1 & $<0.001$ \\
\hline Breast cancer & 1.00 & $0.88-1.13$ & 80.2 & 0.002 \\
\hline Thyroid cancer & 1.31 & $1.07-1.61$ & - & - \\
\hline \multicolumn{5}{|l|}{$\begin{array}{l}\text { After BMI } \\
\text { adjustment }\end{array}$} \\
\hline All & 1.08 & $0.97-1.21$ & 79.4 & 0.001 \\
\hline Breast cancer & 1.00 & $0.88-1.14$ & 79.1 & 0.002 \\
\hline Thyroid cancer & 1.32 & $1.08-1.62$ & - & - \\
\hline \multicolumn{5}{|l|}{ rs11075995 } \\
\hline \multicolumn{5}{|l|}{$\begin{array}{l}\text { Before BMI } \\
\text { adjustment }\end{array}$} \\
\hline Breast cancer & 1.08 & $1.01-1.15$ & 47.2 & 0.150 \\
\hline \multicolumn{5}{|l|}{$\begin{array}{l}\text { After BMI } \\
\text { adjustment }\end{array}$} \\
\hline Breast cancer & 1.08 & $0.89-1.31$ & 61.2 & 0.108 \\
\hline
\end{tabular}

repressing gene, namely retinoblastoma-like 2 [44]. Further studies are necessary to clarify the underlying mechanism between FTO SNP and cancer risk.

Our study has several strengths. First, our study included 27 publications consisting of $\sim 130,000$ cases and $\sim 300,000$ controls, which had the larger statistical power than three previous meta-analyses [33-35]. Second, we presented results without and with adjustment for BMI, but the previous three meta-analyses didn't. Third, besides rs9939609 and its proxy SNP (rs8050136 
and rs17817449), we also investigated two other SNPs (rs1477196 or rs11075995), which are not in high LD with rs9939609. However, several limitations should be noted. First, the effects of gene-gene/gene-environment interactions were not addressed in this meta-analysis as the included individual studies did not provided us with these data. Second, although the total sample size was large enough, it was still limited for some types of cancer. Thus, the subgroup results with limited statistical power should be interpreted with caution. Third, there was significant heterogeneity between studies for three SNPs and the results should be interpreted cautiously.

In conclusion, our updated meta-analysis supported that FTO SNP was associated with some types of cancer, which was mediated by BMI or independent of BMI. Further studies should focus on gene-gene/geneenvironment interaction in the development of cancer. Epigenetics and metabonomics should be paid more attention in order to solve how BMI modify the association between FTO SNP and cancer risk.

\section{MATERIALS AND METHODS}

\section{Literature and search strategy}

We searched PubMed and Embase databases for the potentially eligible studies. The following key words were used to search the eligible publications: (fat-mass and obesity-associated gene OR FTO) and (polymorphism OR variant $O R$ variation OR genotype) and (cancer OR tumor OR carcinoma). We restricted publication language to English. The reference lists of retrieved articles were also hand-searched. The literature search was updated by July 14, 2016.

\section{Inclusion criteria and data extraction}

The included studies met all the following inclusion criteria: (1) investigation of the association of FTO rs9939609 SNP (or any proxy SNP (rs8050136, rs 17817449), $\left.r^{2}>0.90\right)$ or other SNPs which are not in tight LD with rs9939609 (such as rs1477196 and rs11075995) with cancer risk; (2) use of a case-control or cohort design; and (3) provision of an odds ratio (OR) with $95 \%$ confidence interval (CI) with or without adjustment for body mass index (BMI). The following information was extracted from each study: (1) name of the first author; (2) year of publication; (3) country of origin; (4) race/ethnicity of the study population; (5) number of cases and controls; (6) type of cancer; (7) studied SNP; and (8) whether adjusted for BMI in the logistical regression model. Two authors independently reviewed the articles for compliance with the inclusion/ exclusion criteria, resolved disagreements and reached a consistent decision after discussion with the third author.

\section{Statistical analysis}

The associations of FTO SNPs with cancer risk were estimated by calculating the pooled ORs and $95 \%$ CIs under an additive genetic model. The significance of the OR was determined by the $\mathrm{Z}$ test $(p<0.05$ was considered statistically significant). Cochrane's Q test was performed to test the between-study heterogeneity [45, 46]. $I^{2}$ represents the range for degree of heterogeneity. A random-effects (DerSimonian-Laird [45]) or fixed-effects (Mantel-Haenszel [46]) model was used to calculate the pooled OR in the presence ( $p \leq 0.10$ or $\left.I^{2} \geq 50 \%\right)$ or absence $\left(p>0.10\right.$ and $\left.I^{2}<50 \%\right)$ of heterogeneity, respectively. Publication bias was assessed by Begg's test and Egger's test [47] ( $p<0.05$ was considered statistically significant). Data were analyzed using STATA version 11.0 (StataCorp LP, College Station, TX, USA).

\section{Author contributions}

Y.L. conceived, designed and supervised the study. Y.K. wrote the manuscript. Y.K. and F.L. searched the databases, extracted and analyzed the data. All authors reviewed and approved the final manuscript.

\section{CONFLICTS OF INTEREST}

The authors declare no conflicts of interest.

\section{REFERENCES}

1. Frayling TM, Timpson NJ, Weedon MN, Zeggini E, Freathy RM, Lindgren CM, Perry JR, Elliott KS, Lango H, Rayner NW, Shields B, Harries LW, Barrett JC, et al. A common variant in the FTO gene is associated with body mass index and predisposes to childhood and adult obesity. Science. 2007; 316:889-94. doi: 10.1126/science.1141634.

2. Dina C, Meyre D, Gallina S, Durand E, Korner A, Jacobson P, Carlsson LM, Kiess W, Vatin V, Lecoeur C, Delplanque J, Vaillant E, Pattou F, et al. Variation in FTO contributes to childhood obesity and severe adult obesity. Nat Genet. 2007; 39:724-6. doi: 10.1038/ng2048.

3. Xi B, Mi J. FTO polymorphisms are associated with obesity but not with diabetes in East Asian populations: a meta-analysis. Biomed Environ Sci. 2009; 22:449-57. doi: 10.1016/S0895-3988(10)60001-3.

4. Xi B, Wang C, Wang R, Huang Y. FTO gene polymorphisms are associated with obesity and type 2 diabetes in East Asian populations: an update. Obesity (Silver Spring). 2011; 19:236-7; author reply 8. doi: 10.1038/oby.2010.139.

5. Liu C, Mou S, Cai Y. FTO gene variant and risk of overweight and obesity among children and adolescents: a systematic review and meta-analysis. PLoS One. 2013; 8:e82133. doi: 10.1371/journal.pone.0082133. 
6. Brennan P, McKay J, Moore L, Zaridze D, Mukeria A, Szeszenia-Dabrowska N, Lissowska J, Rudnai P, Fabianova E, Mates D, Bencko V, Foretova L, Janout V, et al. Obesity and cancer: Mendelian randomization approach utilizing the FTO genotype. Int J Epidemiol. 2009; 38:971-5. doi: 10.1093/ije/dyp162.

7. Gaudet MM, Yang HP, Bosquet JG, Healey CS, Ahmed S, Dunning AM, Easton DF, Spurdle AB, Ferguson K, O'Mara T, Lambrechts D, Despierre E, Vergote I, et al. No association between FTO or HHEX and endometrial cancer risk. Cancer Epidemiol Biomarkers Prev. 2010; 19:2106-9. doi: 10.1158/1055-9965.EPI-10-0515.

8. Lewis SJ, Murad A, Chen L, Davey Smith G, Donovan J, Palmer T, Hamdy F, Neal D, Lane JA, Davis M, Cox A, Martin RM. Associations between an obesity related genetic variant (FTO rs9939609) and prostate cancer risk. PLoS One. 2010; 5:e13485. doi: 10.1371/journal.pone.0013485.

9. Meyer TE, Boerwinkle E, Morrison AC, Volcik KA, Sanderson M, Coker AL, Pankow JS, Folsom AR. Diabetes genes and prostate cancer in the Atherosclerosis Risk in Communities study. Cancer Epidemiol Biomarkers Prev. 2010; 19:558-65. doi: 10.1158/1055-9965.EPI-09-0902.

10. Delahanty RJ, Beeghly-Fadiel A, Xiang YB, Long J, Cai Q, Wen W, Xu WH, Cai H, He J, Gao YT, Zheng W, Shu XO. Association of obesity-related genetic variants with endometrial cancer risk: a report from the Shanghai Endometrial Cancer Genetics Study. Am J Epidemiol. 2011; 174:1115-26. doi: 10.1093/aje/kwr233.

11. Kaklamani V, Yi N, Sadim M, Siziopikou K, Zhang K, $\mathrm{Xu}$ Y, Tofilon S, Agarwal S, Pasche B, Mantzoros C. The role of the fat mass and obesity associated gene (FTO) in breast cancer risk. BMC Med Genet. 2011; 12:52. doi: 10.1186/1471-2350-12-52.

12. Lurie G, Gaudet MM, Spurdle AB, Carney ME, Wilkens LR, Yang HP, Weiss NS, Webb PM, Thompson PJ, Terada K, Setiawan VW, Rebbeck TR, Prescott J, et al. The obesityassociated polymorphisms FTO rs9939609 and MC4R rs17782313 and endometrial cancer risk in non-Hispanic white women. PLoS One. 2011; 6:e16756. doi: 10.1371/ journal.pone.0016756.

13. Pierce BL, Austin MA, Ahsan H. Association study of type 2 diabetes genetic susceptibility variants and risk of pancreatic cancer: an analysis of PanScan-I data. Cancer Causes Control. 2011; 22:877-83. doi: 10.1007/ s10552-011-9760-5.

14. Tang $H$, Dong $X$, Hassan M, Abbruzzese JL, Li D. Body mass index and obesity- and diabetes-associated genotypes and risk for pancreatic cancer. Cancer Epidemiol Biomarkers Prev. 2011; 20:779-92. doi: 10.1158/10559965.EPI-10-0845.

15. Brooks JD, Bernstein L, Teraoka SN, Knight JA, Mellemkjaer L, John EM, Malone KE, Reiner AS, Lynch CF, Concannon P, Haile RW, Bernstein JL, Group WSC. Variation in genes related to obesity, weight, and weight change and risk of contralateral breast cancer in the WECARE Study population. Cancer Epidemiol Biomarkers Prev. 2012; 21:2261-7. doi: 10.1158/10559965.EPI-12-1036.

16. Hubacek JA, Dlouha D, Bobak M, Jiraskova A, Vitek L. The risk of sporadic colorectal cancer development is not influenced by fat mass and obesity related gene polymorphism in Slavs. Eur J Intern Med. 2012; 23 :e1756. doi: 10.1016/j.ejim.2012.07.002.

17. Kitahara CM, Neta G, Pfeiffer RM, Kwon D, Xu L, Freedman ND, Hutchinson AA, Chanock SJ, Sturgis EM, Sigurdson AJ, Brenner AV. Common obesity-related genetic variants and papillary thyroid cancer risk. Cancer Epidemiol Biomarkers Prev. 2012; 21:2268-71. doi: 10.1158/10559965.EPI-12-0790.

18. Kusinska R, Gorniak P, Pastorczak A, Fendler W, Potemski $\mathrm{P}$, Mlynarski W, Kordek R. Influence of genomic variation in FTO at 16q12.2, MC4R at 18q22 and NRXN3 at 14q31 genes on breast cancer risk. Mol Biol Rep. 2012; 39:2915-9. doi: 10.1007/s11033-011-1053-2.

19. Lim U, Wilkens LR, Monroe KR, Caberto C, Tiirikainen M, Cheng I, Park SL, Stram DO, Henderson BE, Kolonel LN, Haiman CA, Le Marchand L. Susceptibility variants for obesity and colorectal cancer risk: the multiethnic cohort and PAGE studies. Int J Cancer. 2012; 131:E1038-43. doi: 10.1002/ijc.27592.

20. Machiela MJ, Lindstrom S, Allen NE, Haiman CA, Albanes D, Barricarte A, Berndt SI, Bueno-de-Mesquita HB, Chanock S, Gaziano JM, Gapstur SM, Giovannucci E, Henderson BE, et al. Association of type 2 diabetes susceptibility variants with advanced prostate cancer risk in the Breast and Prostate Cancer Cohort Consortium. Am J Epidemiol. 2012; 176:1121-9. doi: 10.1093/aje/ kws 191.

21. Tarabra E, Actis GC, Fadda M, De Paolis P, Comandone A, Coda R, Rosina F. The obesity gene and colorectal cancer risk: a population study in Northern Italy. Eur J Intern Med. 2012; 23:65-9. doi: 10.1016/j.ejim.2011.07.011.

22. Akilzhanova A, Nurkina Z, Momynaliev K, Ramanculov E, Zhumadilov Z, Rakhypbekov T, Hayashida N, Nakashima M, Takamura N. Genetic profile and determinants of homocysteine levels in Kazakhstan patients with breast cancer. Anticancer Res. 2013; 33:4049-59.

23. da Cunha PA, de Carlos Back LK, Sereia AF, Kubelka C, Ribeiro MC, Fernandes BL, de Souza IR. Interaction between obesity-related genes, FTO and MC4R, associated to an increase of breast cancer risk. Mol Biol Rep. 2013; 40:6657-64. doi: 10.1007/s11033-013-2780-3.

24. Garcia-Closas M, Couch FJ, Lindstrom S, Michailidou K, Schmidt MK, Brook MN, Orr N, Rhie SK, Riboli E, Feigelson HS, Le Marchand L, Buring JE, Eccles D, et al. Genome-wide association studies identify four ER negativespecific breast cancer risk loci. Nat Genet. 2013; 45:392-8, 8e1-2. doi: 10.1038/ng.2561.

25. Iles MM, Law MH, Stacey SN, Han J, Fang S, Pfeiffer R, Harland M, Macgregor S, Taylor JC, Aben KK, Akslen LA, 
Avril MF, Azizi E, et al. A variant in FTO shows association with melanoma risk not due to BMI. Nat Genet. 2013; 45:428-32, 32e1. doi: 10.1038/ng.2571.

26. Lin Y, Ueda J, Yagyu K, Ishii H, Ueno M, Egawa N, Nakao H, Mori M, Matsuo K, Kikuchi S. Association between variations in the fat mass and obesity-associated gene and pancreatic cancer risk: a case-control study in Japan. BMC Cancer. 2013; 13:337. doi: 10.1186/1471-2407-13-337.

27. Long J, Zhang B, Signorello LB, Cai Q, Deming-Halverson S, Shrubsole MJ, Sanderson M, Dennis J, Michailidou K, Easton DF, Shu XO, Blot WJ, Zheng W. Evaluating genome-wide association study-identified breast cancer risk variants in African-American women. PLoS One. 2013; 8:e58350. doi: 10.1371/journal.pone.0058350.

28. Zheng W, Zhang B, Cai Q, Sung H, Michailidou K, Shi J, Choi JY, Long J, Dennis J, Humphreys MK, Wang Q, Lu $\mathrm{W}$, Gao YT, et al. Common genetic determinants of breastcancer risk in East Asian women: a collaborative study of 23637 breast cancer cases and 25579 controls. Hum Mol Genet. 2013; 22:2539-50. doi: 10.1093/hmg/ddt089.

29. Zhang B, Li Y, Li L, Chen M, Zhang C, Zuo XB, Zhou FS, Liang B, Zhu J, Li P, Huang ZL, Xuan H, Li W, et al. Association study of susceptibility loci with specific breast cancer subtypes in Chinese women. Breast Cancer Res Treat. 2014; 146:503-14. doi: 10.1007/s10549-014-3041-4.

30. Mojaver M, Mokarian F, Kazemi M, Salehi M. Specific TaqMan allelic discrimination assay for rs1477196 and rs9939609 single nucleotide polymorphisms of FTO gene demonstrated that there is no association between these SNPs and risk of breast cancer in Iranian women. Adv Biomed Res. 2015; 4:136. doi: 10.4103/2277-9175.161532.

31. Zeng X, Ban Z, Cao J, Zhang W, Chu T, Lei D, Du Y. Association of FTO Mutations with Risk and Survival of Breast Cancer in a Chinese Population. Dis Markers. 2015; 2015:101032. doi: 10.1155/2015/101032.

32. Zhao Z, Wen W, Michailidou K, Bolla MK, Wang Q, Zhang B, Long J, Shu XO, Schmidt MK, Milne RL, Garcia-Closas M, Chang-Claude J, Lindstrom S, et al. Association of genetic susceptibility variants for type 2 diabetes with breast cancer risk in women of European ancestry. Cancer Causes Control. 2016; 27:679-93. doi: 10.1007/s10552-016-0741-6.

33. Li G, Chen Q, Wang L, Ke D, Yuan Z. Association between FTO gene polymorphism and cancer risk: evidence from 16,277 cases and 31,153 controls. Tumour Biol. 2012; 33:1237-43. doi: 10.1007/s13277-012-0372-9.

34. Zhao J, Huang X, Yang M, Li M, Zheng J. Association between the FTOrs8050136 polymorphism and cancer risk: a meta-analysis. Fam Cancer. 2016; 15:145-53. doi: 10.1007/s10689-015-9843-7.

35. Huang X, Zhao J, Yang M, Li M, Zheng J. Association between FTO gene polymorphism (rs9939609 T/A) and cancer risk: a meta-analysis. Eur J Cancer Care (Engl). 2016; doi: 10.1111/ecc.12464.
36. Xi B, Takeuchi F, Meirhaeghe A, Kato N, Chambers JC, Morris AP, Cho YS, Zhang W, Mohlke KL, Kooner JS, Shu XO, Pan H, Tai ES, et al. Associations of genetic variants in/near body mass index-associated genes with type 2 diabetes: a systematic meta-analysis. Clin Endocrinol (Oxf). 2014; 81:702-10. doi: 10.1111/cen.12428.

37. He D, Fu MS, Miao S, Hotta K, Chandak GR, Xi B. FTO gene variant and risk of hypertension: A meta-analysis of 57,464 hypertensive cases and 41,256 controls. Metabolism. 2014; 63:633-9. doi: 10.1016/j.metabol.2014.02.008.

38. Liu C, Mou S, Pan C. The FTO gene rs 9939609 polymorphism predicts risk of cardiovascular disease: a systematic review and meta-analysis. PLoS One. 2013; 8:e71901. doi: 10.1371/journal.pone.0071901.

39. Cai X, Liu C, Mou S. Association between fat massand obesity-associated (FTO) gene polymorphism and polycystic ovary syndrome: a meta-analysis. PLoS One. 2014; 9:e86972. doi: 10.1371/journal.pone.0086972.

40. Zimmermann E, Angquist LH, Mirza SS, Zhao JH, Chasman DI, Fischer K, Qi Q, Smith AV, Thinggaard M, Jarczok MN, Nalls MA, Trompet S, Timpson NJ, et al. Is the adiposity-associated FTO gene variant related to allcause mortality independent of adiposity? Meta-analysis of data from 169,551 Caucasian adults. Obes Rev. 2015; 16:327-40. doi: 10.1111/obr.12263.

41. Renehan AG, Tyson M, Egger M, Heller RF, Zwahlen M. Body-mass index and incidence of cancer: a systematic review and meta-analysis of prospective observational studies. Lancet. 2008; 371:569-78. doi: 10.1016/ S0140-6736(08)60269-X.

42. Hernandez-Caballero ME, Sierra-Ramirez JA. Single nucleotide polymorphisms of the FTO gene and cancer risk: an overview. Mol Biol Rep. 2015; 42:699-704. doi: 10.1007/s11033-014-3817-y.

43. Stratigopoulos G, Padilla SL, LeDuc CA, Watson E, Hattersley AT, McCarthy MI, Zeltser LM, Chung WK, Leibel RL. Regulation of Fto/Ftm gene expression in mice and humans. Am J Physiol Regul Integr Comp Physiol. 2008; 294:R1185-96. doi: 10.1152/ajpregu.00839.2007.

44. Berulava T, Horsthemke B. Comment on: Jowett et al. (2010) Genetic variation at the FTO locus influences RBL2 gene expression. Diabetes;59:726-732. Diabetes. 2010; 59:e9; author reply e10. doi: 10.2337/db10-0337.

45. DerSimonian R, Laird N. Meta-analysis in clinical trials. Control Clin Trials. 1986; 7:177-88.

46. Mantel N, Haenszel W. Statistical aspects of the analysis of data from retrospective studies of disease. J Natl Cancer Inst. 1959; 22:719-48.

47. Begg CB, Mazumdar M. Operating characteristics of a rank correlation test for publication bias. Biometrics. 1994; 50:1088-101. 